\title{
Endoscopic Management of Symptomatic Duodenal Duplication Cysts: Two Case Reports
}

\author{
Sara Teles de Campos ${ }^{a}$ Ricardo Rio-Tinto ${ }^{a}$ Miguel Bispo $^{a}$ Susana Marques ${ }^{a}$ \\ Paulo Fidalgo ${ }^{a}$ Jacques Devière ${ }^{a, b}$ \\ aGastroenterology Department, Digestive Oncology Unit, Champalimaud Foundation, Lisbon, Portugal; \\ ${ }^{b}$ Department of Gastroenterology, Hepatopancreatology, and Digestive Oncology, Erasmus University Hospital - \\ Université Libre de Bruxelles, Brussels, Belgium
}

\section{Keywords}

Duodenal duplication cysts · Pancreatitis · Endoscopic marsupialization · Endoscopic ultrasound · Endoscopic retrograde cholangiopancreatography

\section{Abstract}

Background: Duodenal duplication cysts (DDCs) are rare congenital anomalies typically manifesting during childhood. Clinical manifestations are uncommon in adulthood. DDCs were classically treated surgically, but endoscopic treatment has been increasingly reported. Endoscopic cyst marsupialization establishes a communication between the cyst cavity and the duodenal lumen so that the cystic content can be drained continuously into the duodenum. We herein describe two cases of symptomatic DDCs diagnosed in adulthood and submitted to endoscopic marsupialization using different techniques and devices. Case Summary: Case 1: A 23-year-old female patient was admitted with the diagnosis of acute pancreatitis. Endoscopic ultrasound revealed a 35-mm duodenal subepithelial lesion whose proximal limit was immediately distal to the ampulla of Vater and filled with fluid and calcifications. Using a duodenoscope, deroofing of the lesion was made with a diathermic snare. Pathology confirmed the diagnosis of DDC. Case 2: A 41-year- old female, submitted to laparoscopic cholecystectomy 1 month earlier due to suspected lithiasic acute pancreatitis, was admitted due to suspicion of iatrogenic biliary fistula. An endoscopic retrograde cholangiopancreatography was performed and the bile leak was treated. Immediately distal to the papillary orifice, a $20-\mathrm{mm}$ subepithelial lesion was also detected. A biopsy forceps was used to fenestrate its wall, allowing the exit of mucous fluid and stones, and a sphincterotome was used to expand the incision. No recurrence was documented in both cases. Conclusion: These cases highlight DDC as a potential cause for acute pancreatitis in adults and endoscopy as an easy treatment option.

\footnotetext{
(c) 2021 Sociedade Portuguesa de Gastrenterologia. Published by S. Karger AG, Basel
}

\begin{abstract}
Abordagem endoscópica de quistos de duplicação duodenal sintomáticos: a propósito de dois casos clínicos
\end{abstract}

\section{Palavras Chave}

Quistos de duplicação duodenal · Pancreatite · Marsupialização endoscópica · Ecoendoscopia • Colangiopancreatografia retrógrada endoscópica karger@karger.com www.karger.com/pjg

Karger $\stackrel{\text { ' }}{5}$

BOPEN ACCESS
(C) 2021 Sociedade Portuguesa de Gastrenterologia. Published by S. Karger AG, Basel

This is an Open Access article licensed under the Creative Commons Attribution-NonCommercial-4.0 International License (CC BY-NC) (http://www.karger.com/Services/OpenAccessLicense), applicable to the online version of the article only. Usage and distribution for commercial purposes requires written permission.
Correspondence to:

Sara Teles de Campos, sara.t.campos@fundacaochampalimaud.pt 


\section{Resumo}

Introdução: Os quistos de duplicação duodenais (QDD) são anomalias congénitas raras que tipicamente se manifestam durante a infância. As manifestações clínicas são pouco frequentes em adultos. Os QDD eram classicamente tratados cirurgicamente, mas o tratamento endoscópico tem sido crescentemente reportado. A marsupialização endoscópica do quisto estabelece uma comunicação entre a cavidade do quisto e o lúmen duodenal, permitindo que o conteúdo do quisto drene continuamente para o duodeno. Reportamos 2 casos de QDD diagnosticados em adultos e submetidos a marsupialização endoscópica, utilizando diferentes técnicas e dispositivos. Casos clínicos: Caso 1: Doente do sexo feminino, 23 anos, internada por pancreatite aguda. Por ecoendoscopia documentou-se lesão subepitelial duodenal com 35 $\mathrm{mm}$ com limite proximal imediatamente distal à ampola de Vater, preenchida por líquido e calcificações. Usando um duodenoscópio, foi feita marsupialização da lesão com ansa diatérmica. Histologia confirmou o diagnóstico de QDD. Caso 2: Doente do sexo feminino, 41 anos, submetida a colecistectomia laparoscópica 1 mês antes por suspeita de pancreatite aguda litiásica, foi internada por suspeita de fístula biliar iatrogénica. Por CPRE confirmouse fuga biliar que foi tratada. Imediatamente distal ao orifício papilar, foi também detetada uma lesão subepitelial com $20 \mathrm{~mm}$. Uma pinça de biopsia foi usada para fenestrar a sua parede, permitindo a saída de fluido mucoso e cálculos e um esfincterótomo foi usado para expandir a incisão. Não se registou recorrência em nenhum dos casos. Conclusão: Estes casos destacam os QDD como causa potencial de pancreatite aguda em adultos e a endoscopia como possível opção terapêutica.

() 2021 Sociedade Portuguesa de Gastrenterologia. Publicado por S. Karger AG, Basel

\section{Introduction}

Duplication cysts can occur anywhere along the gastrointestinal tract, with the duodenum being the least common location and accounting for $2-12 \%$ of cases [1]. There are various theories regarding the etiology of duodenal duplication cysts (DDCs), all based on a defect during embryological development $[2,3]$. Most patients with DDCs experience symptom onset in the first decade of life $[1,2]$. The initial presentation is variable, but the most commonly reported clinical manifestations are abdominal pain and nausea/vomiting $[1,2]$. Pancreatitis (acute or chronic), hepatitis, cholestasis, failure to thrive or weight loss, gastrointestinal bleeding, cyst infection, and intussusception can also occur $[1,2]$. Few cases of malignant transformation have also been documented in the setting of gastric mucosa heterotopia within the DDC [4]. Diagnostic tools include imaging and endoscopy $[5,6]$. Symptomatic patients traditionally undergo surgical treatment of the cyst, with few cases of endoscopic marsupialization reported in the literature [2, 6-15].

We present two cases of DDCs clinically manifesting in adults with acute pancreatitis that were diagnosed and treated endoscopically.

\section{Case Reports}

\section{Case 1}

A 23-year-old female patient was admitted to the emergency department complaining of acute intense epigastric pain. She mentioned that since the age of 17 , she had had multiple similar episodes of self-limited abdominal pain. The patient had no previous medical history nor medication.

Standard diagnostic workup of acute pancreatitis was performed without findings of severity. Magnetic resonance cholangiopancreatography excluded choledocholithiasis and revealed a cystic lesion in the duodenum wall (Fig. 1).

Endoscopic ultrasound confirmed a $35-\mathrm{mm}$ subepithelial lesion located in the second portion of the duodenum, whose proximal limit was immediately distal to the ampulla of Vater and adjacent to, but independent of, the uncinated process. It had a small quantity of fluid and calcifications. No perilesional lymph nodes were detected. Biliary and pancreatic ducts and pancreatic parenchyma were normal.

A duodenoscopy was performed using a duodenoscope. In the second portion of the duodenum, immediately distal to the major papilla, a bulging subepithelial lesion was detected (Fig. 2a). Using a diathermic snare (small oval stiff Captivator ${ }^{\mathrm{TM}}$; Boston Scientific), deroofing of the cyst, away from the papillary region, was made (ERBE settings: ENDOCUT Q, effect 3, duration 1, cutting interval 6) and a large fragment of the lesion was resected (Fig. 2b). The cystic cavity was completely filled with debris that was removed with the snare and vigorous irrigation (Fig. 2c). No complications occurred.

Histological assessment of the resected specimen was compatible with the diagnosis of DDC, with the surface covered by duodenal-type mucosa and with a single wall, without evidence of heterotopia, dysplasia, or neoplasia.

An endoscopic re-evaluation was performed 1 month later and no residual lesion was seen. No clinical or endoscopic recurrence was detected at 1-year follow-up.

\section{Case 2}

A 41-year-old female was admitted to the emergency department due to acute intense abdominal pain located in the epigastrium and right hypochondrium. No other associated symptoms were reported. One month earlier, the patient had been submitted to laparoscopic cholecystectomy due to acute pancreatitis, assumed as having a lithiasic etiology. 

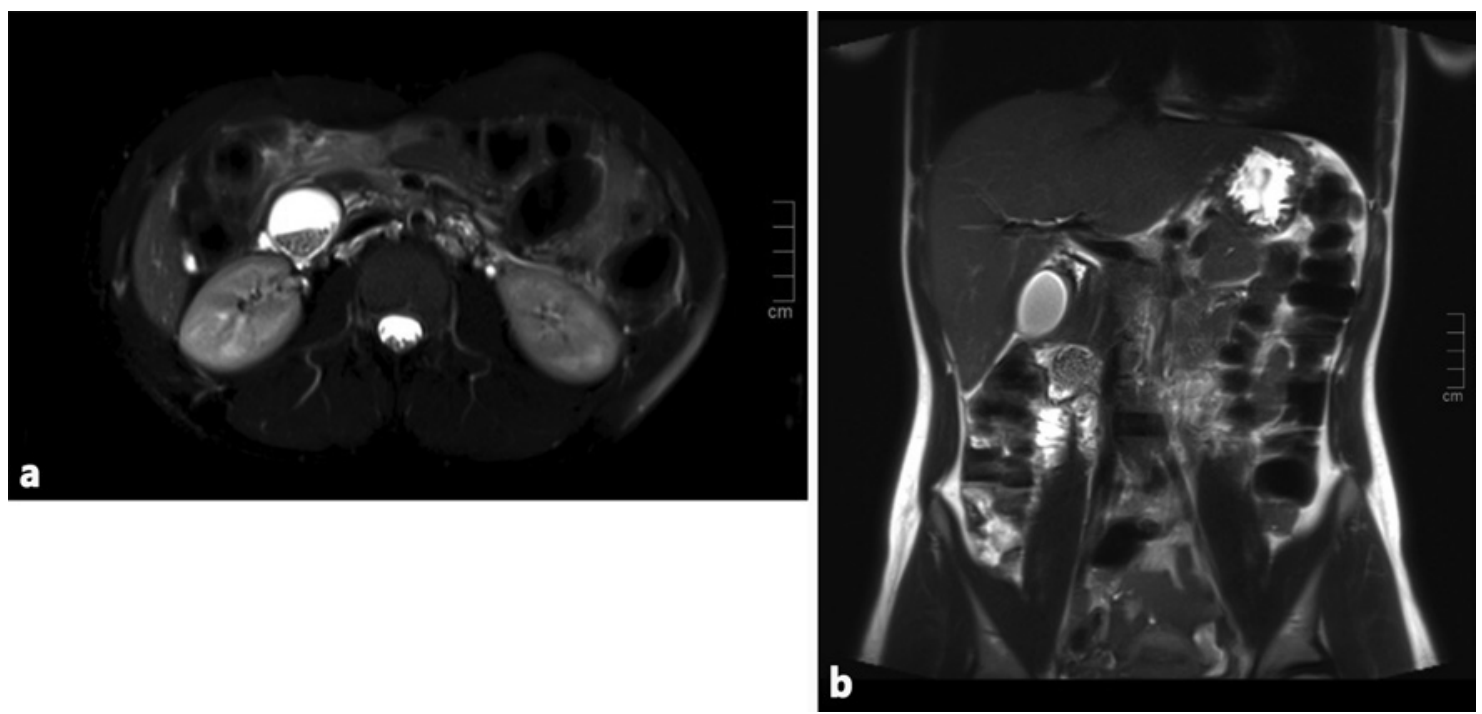

Fig. 1. Case 1. Magnetic resonance cholangiopancreatography images. a Axial T2FS section at the level of the periampullary duplication cyst, with stones in its lumen. b Coronal T2 section, with a gallbladder without lithiasis and the cyst at the duodenal wall.
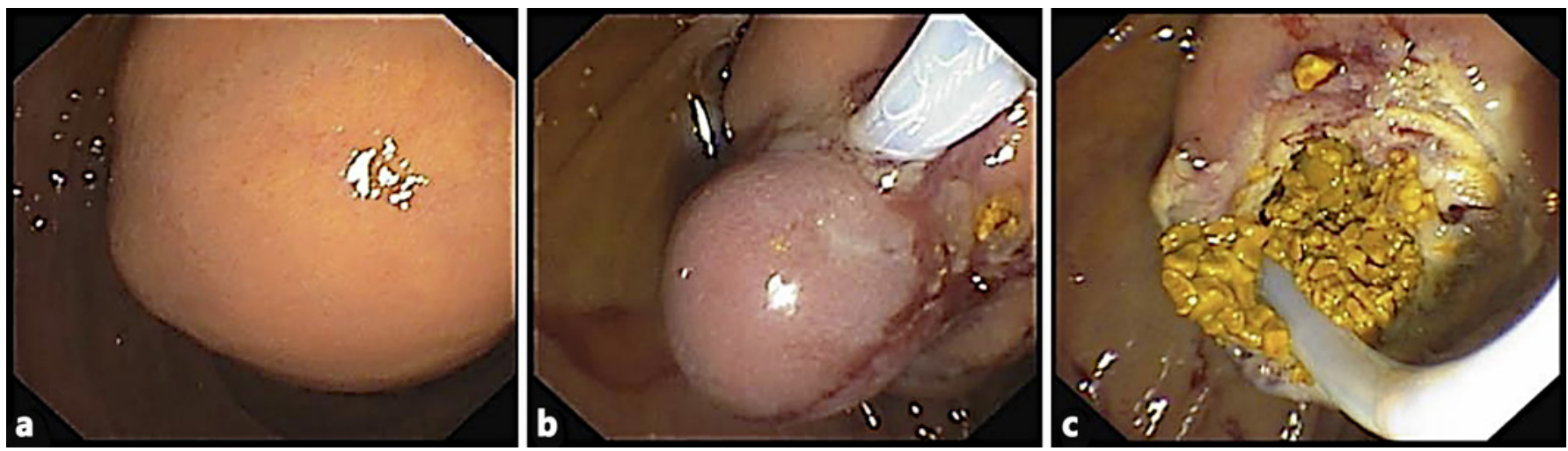

Fig. 2. Case 1. Endoscopic cyst deroofing. a Duodenal bulging subepithelial lesion. $\mathbf{b}$ A large fragment of the lesion was resected with a diathermic snare. c The cystic cavity was filled with stones, which were removed with the snare.

Computed tomography revealed a 20 -mm cystic endoluminal image close to the major papilla, with dense content, suggesting lithiasis.

The patient was submitted to exploratory laparoscopy, and suture of Luschka canaliculi was performed. Nine days later, due to biliary drainage by the abdominal drain, she started a parenteral diet and was submitted to a second exploratory laparoscopy and new suture at the same level. Due to persistence of biliary drainage, 4 days later, the patient was referred for endoscopic retrograde cholangiopancreatography. In the second portion of the duodenum, immediately distal to the papillary orifice, a large bulging subepithelial periampullary lesion with a $20-\mathrm{mm}$ major axis was detected (Fig. 3a). Biliary cannulation was performed and the chol- angiogram showed a nondilated biliary tree without lithiasis and, at the level of the cystic stump, a contrast leak was confirmed (Fig. 3a). A biliary sphincterotomy was performed and a $7 \mathrm{~cm} \times 8.5$ Fr plastic stent was inserted (Fig. 3b, 4b), allowing the resolution of bile leak. The soft duodenal lesion was approached and easily fenestrated with a biopsy forceps. A cystogram was performed, ruling out communication with the biliopancreatic tree (Fig. 4b). Fenestration was expanded with a sphincterotome (ERBE settings: ENDOCUT I, effect 2, cutting duration 3, interval 3; Forced coag $50 \mathrm{~W}$, effect 2), allowing the exit of mucinous fluid and debris (Fig. 3c). The procedure was uneventful.

One month later, endoscopic retrograde cholangiopancreatography was repeated. A residual small duodenal fold was seen 

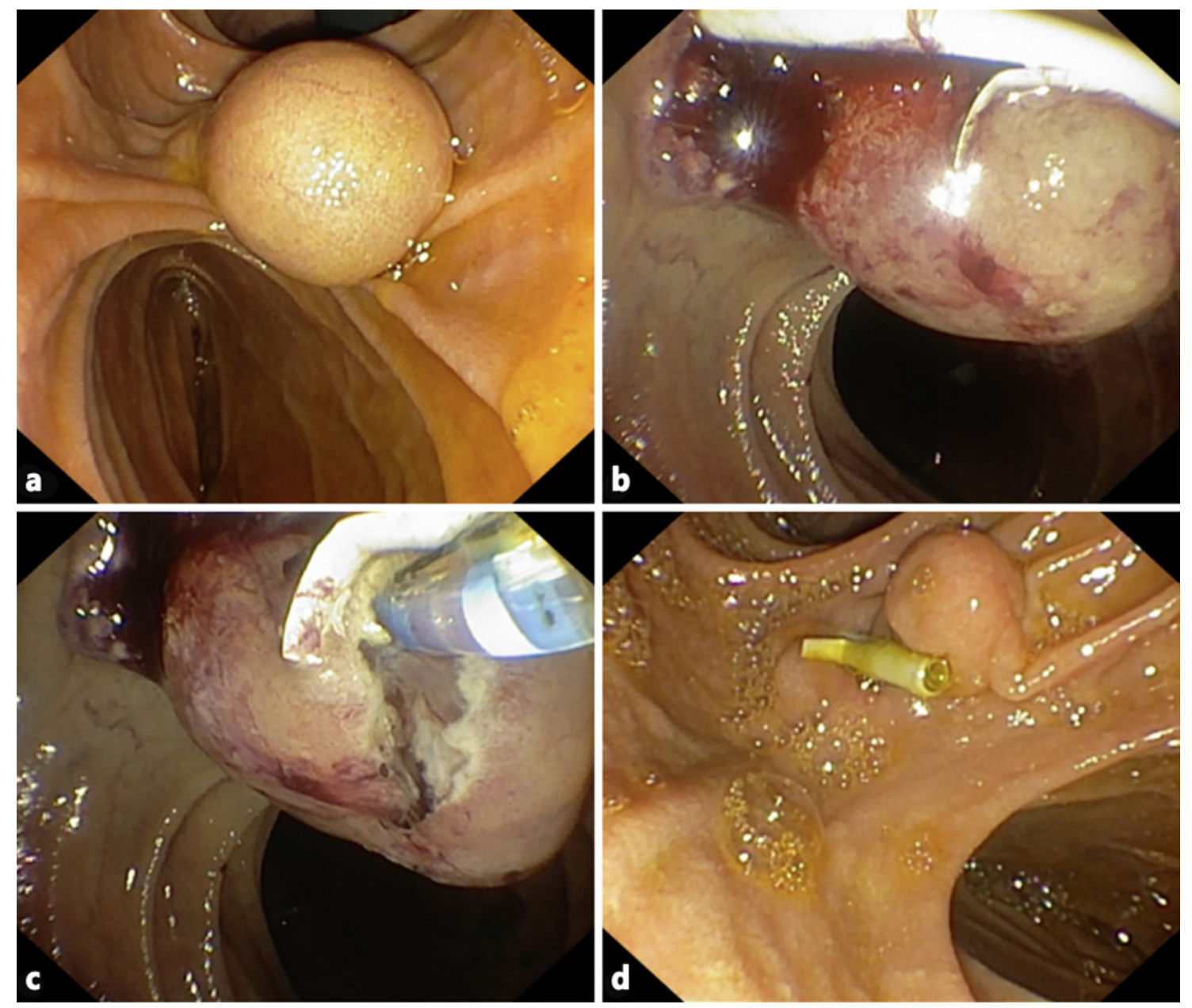

Fig. 3. Case 2. Endoscopy findings. a Duodenal bulging subepithelial lesion. b Status after biliary sphincterotomy and biliary plastic stenting. $\mathbf{c}$ Sphincterotome expanding the incision of the fenestration and allowing the exit of mucinous fluid. d One-month endoscopic re-evaluation showing the biliary stent in situ and a small residual lesion.

(Fig. 3d). The biliary stent was removed and a cholangiogram was repeated, showing no evidence of biliary leak.

A year and a half later, the patient remained asymptomatic, and upper endoscopy (Fig. 5) with a macrobiopsy showed no cyst recurrence.

\section{Discussion}

DDCs represent a minor part of all gastrointestinal tract duplications [5]. The pathogenic mechanism seems to be associated with duodenal epithelial pinching during the outgrowth of the dorsal pancreatic bud or epithelial sequestration $[2,3]$.

The clinical presentation of DDCs depends on the size and location of the cyst and its relationship with nearby anatomical structures. They are generally diagnosed during childhood, with obstructive symptoms being the main complaints [2]. In these two cases, as in others rarely reported before $[7,8,16-18]$, the diagnosis was made with an acute pancreatitis episode occurring during adulthood. In case 1, we can assume that DDC was the cause of acute pancreatitis, as other etiologies had been excluded. In case 2 , the etiology of the acute pancreatitis cannot be fully confirmed, but apart from the lithiasis, the DDC could have also contributed to its development. Several mechanisms related to the presence of a DDC may explain pancreatitis in these patients: (1) transient, mobility-related obstruction of the major papilla outflow by the cyst, (2) and/or compression of the pancreatic duct by a large cyst [2].

DDCs are usually large and located within the second portion of the duodenal wall. They closely mimic a cho- 
Fig. 4. Case 2. Endoscopic retrograde cholangiopancreatography findings. a Cholangiogram showing a cystic stump leak. b Biliary plastic stent placement and cystogram.
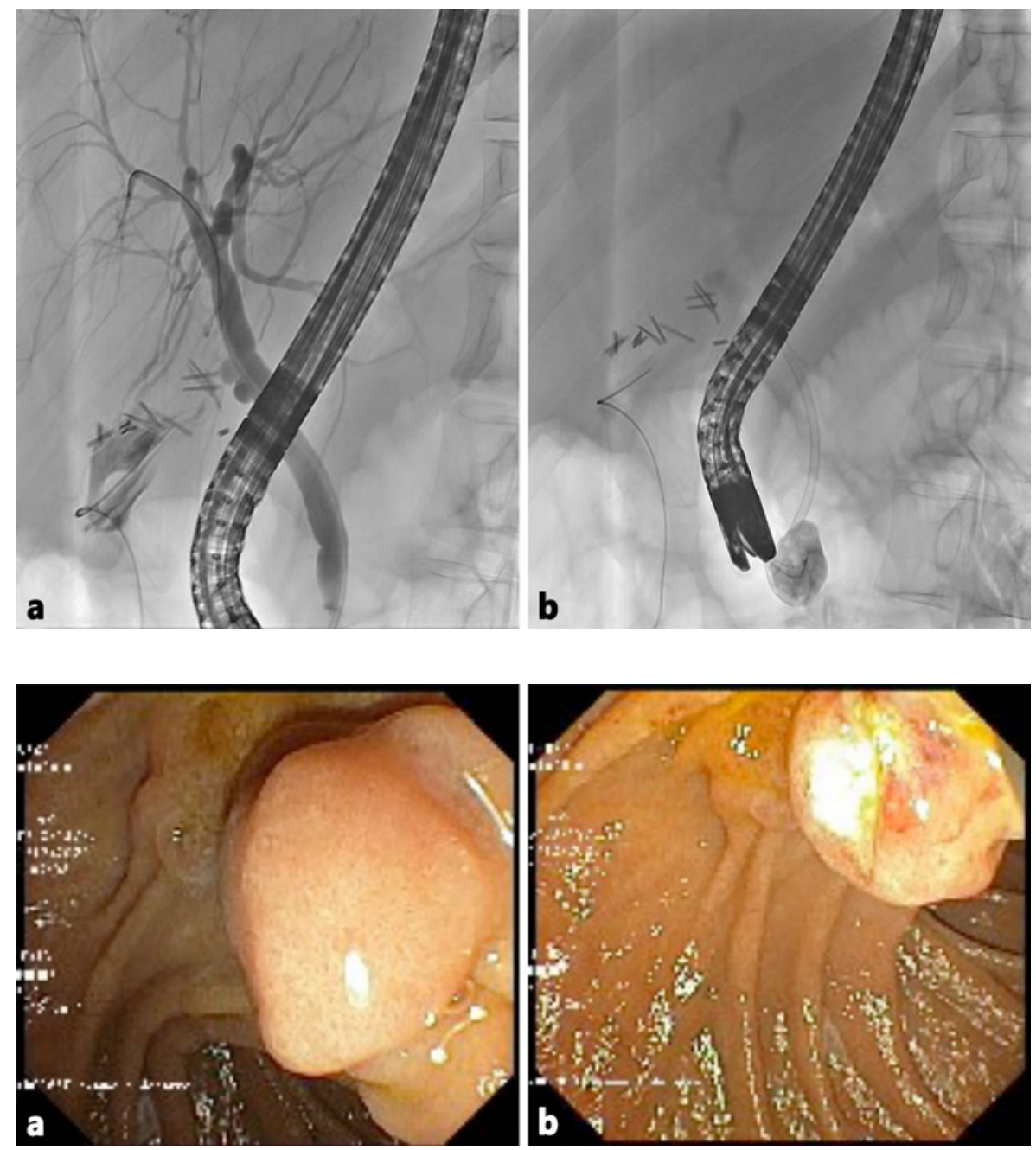

Fig. 5. Case 2. One-year endoscopic surveillance. a A pseudopolyp structure of around $10 \mathrm{~mm}$ was seen near the papilla. b Scar after macrobiopsy performed with a diathermic snare. ledochocele [6,9], and imaging and endoscopic $[5,6]$ tools are important for differentiating these entities. Typically, peripapillary DDCs are located distal to the papilla with no communication with the biliopancreatic structures, while the choledochocele is part of the bile duct, bulging proximally to the papillary orifice [8]. In the cases presented herein, imaging was not sufficient for the diagnosis, probably because of DDCs' rarity and variety in terms of clinical presentation and radiological findings. Endoscopically, the position of the papilla helped distinguish between both. In endoscopic ultrasound, DDCs are documented as being lined by duodenal mucosa and having a distinct muscle layer, whereas choledochoceles are lined by either bile duct or gallbladder mucosa and lack a muscle layer. The internal content may be anechoic or hypoechoic. As in these cases, DDCs can contain thick mucinous material, septations, fluid levels, and debris. In case 1, the presence of enteroliths compromised a complete ultrasonographic evaluation. Enteroliths inside DDCs have been previously reported and may be attributed to food stasis and alkalinity [19]. Pathological assessment, as performed in case 1, helps confirm the diagnosis and exclude (pre)malignant transformation.

The treatment of DDCs was traditionally surgical [3], which was associated with a high morbidity, due to the proximity of the cyst to the papilla and the biliopancreatic confluence. It might even end up with a pancreaticoduodenectomy. Since 1984, successful endoscopic therapy for intraluminal duplication cysts, using different methods for creating a wide and persistent opening of the anterior portion of the cyst, has been reported [6-15]. It can be done by resecting the cyst roof using a standard polypectomy snare or by a large marsupialization in the roof using a sphincterotome, a needle knife, or an endoscopic dissection knife. Endoscopic cyst management has been shown to have a high technical and clinical success, with faster recovery 
times compared to surgery $[8,20]$. The only complication previously reported during endoscopic treatment of DDCs is bleeding, successfully managed during the procedure [8] The theoretical disadvantage is the partial resection of the cyst, which does not allow to totally exclude the presence of gastric metaplasia or dysplasia. To overcome this limitation, as much as possible of the cyst wall should be excised during endoscopic treatment. For this reason, snare excision of the bottom should be the preferred technique, and a 1-year follow-up endoscopy is recommended.

These cases highlight the need to consider DDC in the differential diagnosis of acute pancreatitis in adults and the possibility of endoscopic cyst marsupialization as its first-line treatment.

\section{Statement of Ethics}

The authors declare that the procedures followed were in accordance with the regulations of the relevant clinical research ethics committee and with those of the Code of Ethics of the World Medical Association (Declaration of Helsinki). The patients provided both verbal and written consent for publication of this case report and accompanying images. A copy of the written consent remains available for review. The authors declare that they have followed the protocols of their work center on the publication of patient data.

\section{Conflict of Interest Statement}

The authors have no conflicts of interest to declare.

\section{Funding Sources}

None.

\section{Author Contributions}

All authors were involved in patient care and read and approved the manuscript. S.T. de Campos served as the principal author and was engaged in the collection of data and in manuscript writing. R. Rio-Tinto, M. Bispo, and J. Devière diagnosed, treated, and followed the patients. P. Fidalgo, M. Bispo, S. Marques, R. RioTinto, and J. Devière contributed by critically reviewing the manuscript.

\section{References}

1 Chen JJ, Lee HC, Yeung CY, Chan WT, Jiang $\mathrm{CB}$, Sheu JC. Meta-analysis: the clinical features of the duodenal duplication cyst. J Pediatr Surg. 2010 Aug;45(8):1598-606.

2 Dipasquale V, Barraco P, Faraci S, Balassone V, De Angelis P, Di Matteo FM, et al. Duodenal Duplication Cysts in Children: Clinical Features and Current Treatment Choices. Biomed Hub. 2020 Jul;5(2):152-64.

3 Merrot T, Anastasescu R, Pankevych T, Tercier S, Garcia S, Alessandrini P, et al. Duodenal duplications. Clinical characteristics, embryological hypotheses, histological findings, treatment. Eur J Pediatr Surg. 2006 Feb;16(1):18-23.

4 Seeliger B, Piardi T, Marzano E, Mutter D, Marescaux J, Pessaux P. Duodenal duplication cyst: a potentially malignant disease. Ann Surg Oncol. 2012 Nov;19(12):3753-4.

5 Liu R, Adler DG. Duplication cysts: Diagnosis, management, and the role of endoscopic ultrasound. Endose Ultrasound. 2014 Jul;3(3):152-60.

6 Schils N, Vandecaveye V, Van Overbeke L, Laleman W. Endoscopic treatment of a symptomatic duodenal duplication cyst. Endoscopy. 2018 Jul;50(7):E184-5.

7 Arantes V, Nery S, Starling S, Albuquerque W, Alberti L. Duodenal duplication cyst causing acute recurrent pancreatitis, managed curatively by endoscopic marsupialization. Endoscopy. 2012;44(Suppl 2 UCTN):E117-8.
8 Antaki F, Tringali A, Deprez P, Kwan V, Costamagna G, Le Moine O, et al. A case series of symptomatic intraluminal duodenal duplication cysts: presentation, endoscopic therapy, and long-term outcome (with video). Gastrointest Endosc. 2008 Jan;67(1):163-8.

9 Rana SS, Sharma R, Gupta R. Duplication cyst obscuring major duodenal papilla. Ann Gastroenterol. 2019 Jul-Aug;32(4):423.

10 Martínez-Alcalá García F, Peréz Pozo JM, Martínez-Alcalá García A, Ciria Ávila JA, Martínez Alcalá F. Duodenal duplication cyst and its endoscopic resolution. Gastroenterol Hepatol. 2014 Apr;37(4):274-5. Spanish.

11 Sin EI, Salazar E, Khor CJ, Low Y. Endoscopic decompression and marsupialization of a duodenal duplication cyst. J Pediatr Surg Case Rep. 2018 Jun;33:37-40.

12 Kurien R, Chowdhury S, Unnikrishnan L, Simon E, Dutta A, Mahanta K, et al. Endoscopic treatment of a duodenal duplication cyst. Endoscopy. 2014;46(Suppl 1 UCTN):E583-4.

13 Salazar E, Sin EI, Low Y, Khor CJ. Insulatedtip knife: an alternative method of marsupializing a symptomatic duodenal duplication cyst in a 3-year-old child. VideoGIE. 2018 Sep;3(11):356-7.

14 Meier AH, Mellinger JD. Endoscopic management of a duodenal duplication cyst. J Pediatr Surg. 2012 Nov;47(11):e33-5.
15 Ma MX, Awadie H, Bourke MJ. Treatment of large duodenal duplication cyst using endoscopic submucosal dissection knife. VideoGIE. 2017 Jul;2(9):223-4.

16 Stelling T, von Rooij WJ, Tio TL, Reeders JW, Bartelsman JJ, Tytgat GN. Pancreatitis associated with congenital duodenal duplication cyst in an adult. Endoscopy. 1987 Jul;19(4):171-3.

17 Guarise A, Faccioli N, Ferrari M, Romano L, Parisi A, Falconi M. Duodenal duplication cyst causing severe pancreatitis: imaging findings and pathological correlation. World J Gastroenterol. 2006 Mar;12(10):1630-3.

18 Perrod G, Rahmi G, Samaha E, Vienne A, Cellier C. Duodenal duplication cyst: a rare cause of recurrent pancreatitis. VideoGIE. 2018 Jan;3(2):58-60.

19 Ardengh JC, Brunaldi MO, Kemp R, Santos JS. Duodenal duplication cyst with enteroliths diagnosed by echoendoscopy and treated by endoscopic marsupialization. Arq Gastroenterol. 2020 Jan-Mar;57(1):110-1.

20 Gjeorgjievski M, Manickam P, Ghaith G, Cappell MS. Safety and efficacy of endoscopic therapy for nonmalignant duodenal duplication cysts: case report and comprehensive review of 28 cases reported in the literature. Medicine (Baltimore). 2016 May;95(22): e3799. 